\title{
Stem cells by any other name
}

The tricky word 'embryonic' is to be removed from the name of the US Human Embryonic Stem Cell Registry, the National Institutes of Health announced last week. It will be renamed the Human Pluripotent Stem Cell Registry.

The change results from an executive order issued by President George W. Bush after he vetoed legislation that would have lifted some restrictions on federal funding for human embryonic stem-cell research (see Nature doi:10.1038/news070618-13; 2007). The order was widely viewed as an attempt to downplay the potential of human embryonic stem cells. Even its title is politically charged: "Expanding Approved Stem Cell Lines in Ethically Responsible Ways."

But Charis Thompson, a professor of rhetoric and a member of the Berkeley Stem Cell Center in California, says both sides play at that game: advocates of embryonic stem-cell research avoid using terms such as 'embryo' and 'cloning', she observes. “This kind of linguistic deflation of public anxiety is a hallmark of moving ahead in this field in the United States and will only intensify," Thompson says.

Besides removing 'embryonic' from the names of the cell lines that can receive federal research funding - as instructed in the executive "Pluripotency order - the 18 September announcement sets out a strategy of awarding grants to create cell lines without the involvement of embryos, adding more funds to existing grants and "aggressively pursuing an assessment of the potential of alternative sources of pluripotent stem-cell lines".

This rankles with many scientists working to create pluripotent stem-cell lines, who say that such an assessment is not possible without research on newly derived embryonic stem-cell lines. "It's not an alternative; these are complementary technologies," says Rudolf Jaenisch at the Whitehead Institute in Cambridge, Massachusetts, who is working to reprogramme non-embryonic cells to be as flexible as embryonic stem cells.

One problem is that pluripotency is a notoriously imprecise term. Not even human embryonic stem cells have been established as is a notoriously imprecise term." pluripotent, as researchers have yet to establish their ability to become all human cell types, says

Glyn Stacey, head of the UK Stem Cell Bank in Hertfordshire, which handles stem-cell lines created from embryos as well as those derived from fetal and adult tissues.

The first non-embryonic stem-cell lines could be added to the registry in the next few months.

Monya Baker

See editorial, page 377. \&Therapeutics

\section{Read others' thoughts. Discuss points of view. Connect in clinical pharmacology}

\author{
Why use Nature Network?
}

- Create a personal profile page for you and your research

- Build your own global online network

- Form a group for your lab, department/division, institution or organization

- Search comprehensive listings of upcoming seminars and conferences

- Post your own events to local calendars

Clinical Pharmacology \& Therapeutics, now on Nature Network.

Extend your thoughts and share your knowledge.

http://network.nature.com/group/cpt

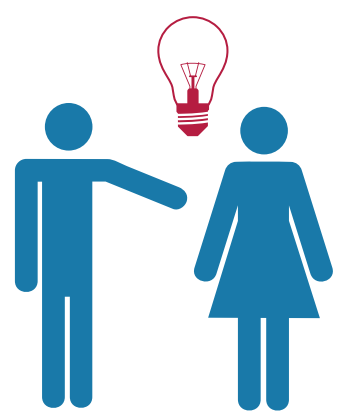

